\title{
Penilaian Pembelajaran Sejarah Konstruktivistik: Pendekatan Critical Discourse Analysis
}

\author{
Nur Fatah Abidin', Hermanu Joebagio ${ }^{2}$, dan Sariyatun ${ }^{3}$ \\ ${ }^{1}$ Mahasiswa Magister Pendidikan Sejarah Universitas Sebelas Maret Surakarta \\ ${ }^{2}$ Dosen Magister Pendidikan Sejarah Universitas Sebelas Maret Surakarta ${ }^{3}$ Dosen \\ Magister Pendidikan Sejarah Universitas Sebelas Maret Surakarta \\ 1ikbenfatah@gmail.com, 2hermanu.joebagio@gmail.com, ${ }^{3}$ sari_fkip_uns@yahoo.co.id
}

\begin{abstract}
This article discusses about assessment of the constructivism approach in history learning with Critical Discourse Analysis (CDA). CDA provides a set of in-depth analysis method which includes the realm of linguistic, social, and cultural. The CDA is composed of three stages of a dynamic analysis and related to each other: (1) analysis of the text, (2) analysis of the practice of discourse, and (3) analysis of social practices. In the context of history learning with constructivism approach, the third stages can be used to assess the development of the system and the structure of the thinking of learners. CDA approach can be used to analyse the work of learners with description test. Therefore, the necessary rubric based on assessment rubrics and discourse analysis of the level of development of thinking learners. Based on the research results, the CDA can be used in learning history, specifically with constructivism approach. Assessment of history learning with constructivism approach is expected to be an alternative assessment of learning that not only assess student knowledge of quantity, but also to measure the development of the system and the structure of the thinking of learners.
\end{abstract}

Keywords: Assessment, Constructivist of Learning History, Critical Discourse Analysis

\begin{abstract}
ABSTRAK
Tulisan ini mendiskusikan mengenai penilaian dalam pembelajaran sejarah konstruktivistik dengan pendekatan Critical Discourse Analysis (CDA). CDA menyediakan seperangkat metode analisis yang mendalam yang mencakup ranah linguistik, sosial, dan kultural. CDA terdiri dari tiga lapisan analisis yang dinamis dan terkait satu sama lain yaitu: (1) analisis teks, (2) analisis praktik kewacanaan, dan (3) analisis praktik sosial. Dalam konteks pembelajaran sejarah konstruktivistik, ketiga lapisan tersebut dapat digunakan untuk menilai perkembangan sistem dan struktur berpikir dari peserta didik. Pendekatan CDA dapat digunakan untuk menganalisis hasil kerja peserta didik berbentuk tes uraian. Oleh karena itu, diperlukan rubrik ancangan analisis wacana dan rubrik penilaian tingkat perkembangan berpikir peserta didik. Berdasarkan hasil penelitian, CDA dapat digunakan dalam pembelajaran sejarah, khususnya pembelajaran berparadigma konstruktivisme. Penilaian pembelajaran sejarah konstruktivistik ini diharapkan dapat menjadi alternatif penilaian pembelajaran yang tidak hanya menilai kuantitas pengetahuan siswa saja, tetapi juga mengukur perkembangan sistem dan struktur berpikir dari peserta didik.
\end{abstract}

Kata Kunci: Penilaian, Pembelajaran Sejarah Konstruktivistik, Critical Discourse Analysis 


\section{PENDAHULUAN}

Penilaian merupakan aspek penting dalam proses pembelajaran. Penilaian ditujukan untuk mengetahui kelebihan dan kekurangan peserta didik, mengamati kemajuan peserta didik, memberi nilai peserta didik serta mengukur efektifitas dari proses pembelajaran (Popham, 1995). Penilaian dapat dilaksanakan melalui tiga jenis yaitu penilaian diagnostik, formatif dan sumatif (Johnson dan Johnson, 2002), yang melingkupi penilaian di ranah kognitif, afektif dan psikomotorik.

Penilaian pembelajaran berkaitan erat dengan paradigma pembelajaran serta subjek mata pelajaran. Dalam arti lain, setiap paradigma pembelajaran serta mata pelajaran membutuhkan suatu bentuk atau metode penilaian masingmasing. Misalnya, penilaian dalam paradigma pembelajaran behaviorisme akan membutuhkan perangkat penilaian yang berbeda dengan penilaian pembelajaran dengan paradigma konstruktivistik. Begitu juga penilaian dalam mata pelajaran sejarah akan berbeda dengan pembelajaran geografi. Selain dua aspek tersebut, komponen pembelajaran lain juga perlu diperhatikan dalam menentukan bentuk penilaian pembelajaran, misalnya tingkat kemampuan peserta didik, efektifitas ataupun ketersediaan sarana dan prasarana (Reynold, Livingston dan Wilson, 2010).

Pendidik memiliki peran penting dalam menentukan bentuk dan jenis penilaian yang sesuai dengan kebutuhan peserta didik. Pendidik memiliki beragam pilihan dalam memilih bentuk penilaian yang digunakan dalam proses pembelajaran. Bentuk-bentuk penilaian pembelajaran misalnya penilaian obyektif, subyektif, non-tes, portofolio dan penilaian berbasis kelas yang dapat digunakan sesuai dengan kebutuhan peserta didik (Budiyono, 2015).

Tulisan ini mendiskusikan kerangka awal penilaian pembelajaran sejarah konstruktivistik dengan pendekatan Critical Discourse Analysis (CDA). Pemilihan fokus kajian pada pembelajaran sejarah konstruktivistik ditujukan untuk memperkuat proses pembelajaran sejarah, khususnya dalam ranah penilaian dan evaluasi pembelajaran yang konstruktivistik.

CDA merupakan suatu metode analisis yang berakar dari pemikiran Michael Foucault (1980) mengenai discourse atau wacana. Dalam perspektif Foucault, tidak ada kemungkinan kebenaran di luar wacana. CDA dalam kerangka tersebut menyediakan seperangkat alat untuk menganalisis bagaimana praktik wacana dikonstruksi, dikonsumsi dan dipraktikan dalam masyarakat (Fairclough, 1989). 
CDA banyak digunakan di ranah linguistik, politik, sosial, serta bidang penelitian yang lain. Telaah representatif mengenai analisis wacana dalam pembelajaran dipaparkan oleh Rebecca Rogers, dkk (2004). Rogers, dkk menyusun kajian mengenai kemungkinan penggunaan pendekatan CDA dalam pembelajaran. Satu artikel yang relevan dengan kajian dalam tulisan ini ditulis oleh Loukia K. Sarroub mengenai penilaian literasi antara pendidik dan peserta didik dalam proses reflection dan action. Kajian Sarroub ini menjadi landasan bahwa CDA dapat digunakan sebagai perangkat penilaian dalam pembelajaran.

Kajian lain yang relevan ditulis oleh Margaret Walshaw (2007). Walshaw menekankan bahwa CDA yang dirumuskan oleh Norman Fairclough (1989) merupakan perangkat analisis yang dapat digunakan dalam proses pembelajaran. Namun, dalam hal ini Walshaw menempatkan CDA tidak dalam ruang pendekatan penilaian pembelajaran, tetapi lebih kepada proses pembelajaran berbasis analisis wacana.

Sementara itu, di ranah pembelajaran sejarah, pendekatan CDA masih jarang disentuh sebagai suatu komponen pendekatan pembelajaran. Padahal, secara teoretik CDA memuat seperangkat metode atau cara untuk mengetahui perkembangan sistem dan struktur kognitif, afektif, serta psikomotorik peserta didik. Pengukuran terhadap perkembangan sistem dan struktur kognitif tersebut menjadi bagian penting dalam proses pembelajaran konstruktivistik yang tidak hanya menekankan pada kuantitas pengetahuan saja, tetapi juga kualitas pengetahuan peserta didik (Schunk, 2012).

Berdasarkan paparan tersebut, tulisan ini mengawali kajian konseptual terhadap pendekatan CDA dalam proses pembelajaran sejarah. Sebagai kajian awal, telaah akan mencakup kerangka penilaian pembelajaran sejarah dengan pendekatan CDA secara makro. Telaah makro ini diharapkan dapat mendorong kajian yang lebih mendalam mengenai penilaian pembelajaran sejarah konstruktivistik.

\section{METODE}

Metode yang digunakan adalah kualitatif dengan pendekatan studi literatur yang mengarah pada methodological review antara pembelajaran sejarah, konstruktivisme dan Critical Discourse Analysis (CDA). Langkah penelitian terdiri dari tiga tahap yaitu meliputi: (1) literature dan methodological review, (2) analisis data literatur dan data dalam kategori metodologis, dan (3) melaporkan hasil analisis. Langkah pertama bertumpu pada kajian literatur dan metodologis terhadap paradigma konstruktivisme dalam 
pembelajaran sejarah, pendekatan CDA, serta konsep penilaian dalam pembelajaran sejarah konstruktivistik. Analisis data mempertautkan aspek literatur dan metodologis yang mengarah pada sintesis metode dan konsep.

\section{PEMBAHASAN}

\section{Konstruktivisme dalam Pembelajaran Sejarah}

Pembelajaran dalam pengertian luas didefinisikan sebagai beragam proses dalam diri individu yang mengarah pada perubahan kapasitas pengetahuan dan keterampilan secara permanen dimana proses perubahan tersebut tidak disebabkan semata-mata oleh penuaan atau kematangan biologis (Illeris, 2011: 10). Secara lebih spesifik, khususnya dalam konteks pendidikan, pembelajaran didefinisikan sebagai rangkaian kegiatan belajar yang direncanakan dan diciptakan untuk mempengaruhi peserta didik atau mengubah perilaku peserta didik (Suparman, 2012). Tujuan yang hendak dicapai dalam proses pembelajaran adalah penguasaan dan peningkatan kemampuan peserta didik di bidang pengetahuan atau kognitif, sikap atau afektif dan ketrampilan atau psikomotorik (Arikunto, 2010).

Sejarah adalah rekonstruksi aktivitas dan perkembangan manusia baik dalam bentuk peristiwa, pemikiran, mentalitas, intelektualitas di masa lalu yang bermakna sosial untuk kepentingan masa kini dan masa depan (Kuntowijoyo, 2013). Rekonstruksi masa lalu dilakukan untuk memenuhi suatu rasa ingin tahu mengenai masa lampau, hasrat untuk menerangkan asal usul budaya, semangat patriotik kepada asal usul negeri, kehendak untuk mengerti latar belakang sosial dan suasana intelektual. Suatu pencarian untuk menemukan "pelajaran sejarah" yang akan membantu manusia era kontemporer untuk memecahkan masalah-masalahnya, keinginan untuk menemukan di dalam bacaan sejarah ilustrasi-ilustrasi yang efektif bagi pencocokan dari suatu argumen atau suatu generalisasi serta pendalaman mengenai suatu metode pada masa lampau untuk masa lampau itu sendiri (Gottschalk, 2008).

Dimensi temporal sejarah dengan demikian mencakup masa lalu, masa kini dan masa depan. Sejarah tidak hanya semata-mata mempelajari masa lalu atau bersifat antikuarian. Sejarah merupakan proses interaksi berkesinambungan antara sejarawan dengan fakta-faktanya, dialog tanpa akhir antara masa kini dan masa lalu (Carr, 2014: 35). Dalam kaitannya dengan lintasan waktu masa lalu, masa kini dan masa depan, sejarah merupakan aktivitas mewariskan ingatan dan menyemai kesadaran jati diri yang membantu individu atau masyarakat masa kini untuk memahami realitas sosial kontemporer. Rekonstruksi sejarah dapat 
disebut sebagai kilasan sejarah sesaat atau instant history yang terus menerus direproduksi untuk kepentingan masa kini. Melalui kilasan sejarah, masyarakat kontemporer membangun pemahaman, ingatan sejarah dan jati diri dalam konteks kehidupannya di masa kini dan masa mendatang. Hal ini menjadi penting, khususnya bagi generasi kekinian yang tidak mengalami langsung kejadiankejadian sejarah (Gillis, 1994:

3). Dengan demikian, tujuan pembelajaran sejarah mencakup tiga aspek, yaitu kognitif melalui transfer of knowledge, afektif melalui transfer of value, dan konasi melalui transfer of virtue.

Pembelajaran sejarah konstruktivistik mengacu pada aktivitas pembelajaran sejarah yang bersandar pada paradigma konstruktivisme. Konstruktivisme dalam ranah pendidikan memandang bahwa peserta didik secara otonom membangun atau mengkonstruksi pengetahuan dan kecerdasan melalui interaksi dengan dunia fisik dan sosial (Schunk, 2012: 320322). Belajar dalam paradigma konstruktivisme adalah: (1) belajar merupakan sebuah proses aktif; (2) pembelajaran terbaik adalah menyelesaikan berbagai konflik ide atau konsepsi melalui pengalaman, refleksi dan metakognisi; (3) belajar adalah pencarian dan pengkonstruksian makna oleh peserta didik; (4) konstruksi dapat dikatakan mencapai titik ideal jika menyentuk proses-proses sosial; (5) belajar secara mendalam dengan mengkonstruksi pengetahuan secara menyeluruh atau holistik dan berkaitan;

(6) pendidik berperan untuk memberdayakan peserta didik untuk menemukan dan merefleksikan pengalaman realistik (Muijs \& Reynold, 2008: 98-99).

Dalam konteks pembelajaran sejarah, paradigma konstruktivisme menjadikan pembelajaran sejarah bukan hanya dipandang sebagai proses statis dan antikuarian dalam mempelajari peristiwa di masa lalu. Secara teoretik, pembelajaran sejarah konstruktivistik memandang bahwa peserta didik secara dinamis dan otonom membangun atau mengkonstruksi pengetahuan dan kecerdasan melalui interaksi dengan dunia fisik dan sosial. Oleh karena itu, pembelajaran sejarah dengan pendekatan konstruktivistik idealnya disusun secara tematik dan memuat problematika, konsep-konsep pokok, serta ide konseptual secara holistik. Proses pembelajaran memfokuskan pada aktivitas manipulatif yang mengarahkan peserta didik untuk menganalisis, mengevaluasi dan mengkonstruksi pengetahuan dan pemahaman mengenai sejarah (Schunk, 2012: 368). 
Berdasarkan paparan tersebut, Pengetahuan dalam paradigma pembelajaran sejarah konstruktivistik tidak mementingkan kuantitas konstruktivisme berasal dari peserta didik dan bukan semata-mata diserap dari penguasaan pengetahuan kesejarahan.

Aspek penting dalam proses pendidik. Dengan demikian, setiap peserta didik dapat membangun konstruksi pembelajaran sejarah konstruktivistik adalah perkembangan sistem dan struktur berpikir dari peserta didik. Pengukuran tingkat pencapaian kognitif dan afektif dilakukan dengan menggunakan taksonomi Bloom yang kemudian direvisi oleh Anderson dan Krathwolh. Dalam taksonomi tersebut dirumuskan tingkat pencapaian kognitif mulai dari: (1) remember atau mengingat, (2) understand atau memahami, (3) apply atau menerapkan, (4) analyse atau menganalisis, (5) evaluate atau mengevaluasi, (6) create atau mencipta (Anderson dan Krathwolh, 2015). Sementara pada ranah afektif, Bloom (1965) merumuskan taksonomi belajar mulai dari: (1) receiving atau menerima, (2) responding atau menanggapi, (3) valuing atau menilai, (4) organizing atau mengatur, (5) characterization atau menginternalisasi dalam diri.

Aspek lain yang perlu diperhatikan dalam pembelajaran sejarah konstruktivistik adalah sifat plural yang dihasilkan dalam proses pembelajaran. Pluralisme diartikan bahwa peserta didik diberi kesempatan untuk mengartikulasikan temuan dan argumentasinya secara otonom. pengetahuan yang beranekaragam dan berbeda satu sama lain atau mutliple reality (Muijs \& Reynold, 2008: 99-103). Sifat multiple reality ini menghasilkan dilema dalam proses penilaian pembelajaran. Dalam konteks tersebut, terjadi demokratisasi kebenaran di dalam kelas. Peserta didik diberi kesempatan dan peluang untuk mengutarakan kebenaran berdasarkan proses konstruksi yang dilakukannya dalam pembelajaran. Dengan demikian, proses pembelajaran tidak menuntut pada kebenaran tunggal yang diujarkan oleh pendidik.

Berdasarkan dua hal tersebut, diperlukan penilaian pembelajaran sejarah konstruktivistik sebagai usaha untuk mengakomodasi penilaian perkembangan sistem dan struktur yang disertai dengan adanya multiple reality.

Penilaian pembelajaran dengan pendekatan critical discourse analysis diajukan untuk memenuhi kebutuhan tersebut.

\section{Pendekatan Critical Discourse Analysis}

Asumsi dalam Critical Discourse Analysis (CDA) menempatkan wacana atau discourse, baik dalam bentuk teks ataupun tuturan, sebagai titik penting 
dalam praktik kehidupan di segala bidang. Konsekuensi dari asumsi tersebut adalah pentingnya keberadaan suatu wacana sebagai titik dasar dari suatu kajian penelitian (Fairclough, 1989). CDA terdiri dari tiga lapisan analisis yang dinamis dan terkait satu sama lain yaitu: (1) analisis teks, (2) analisis praktik kewacanaan, serta (3) analisis praktik sosial.

Lapisan analisis pertama adalah analisis teks atau juga disebut fase deskripsi. Lapisan analisis teks dikaji dengan menggunakan pendekatan tekstual, linguistik, dan komunikasi. Dalam hal ini, telaah teks fokus pada deskripsi teks, meliputi kosakata, gramatika, dan struktur tekstual. Analisis difokuskan pada aspek kebahasaan dan tekstualitas untuk menjelaskan tendensi, dominasi dan resistensi yang diwujudkan dalam kata atau istilah yang ada di dalam teks tersebut (Titscher, Mayer, Wodak, dan Vetter, dalam Ibrahim, 2009: 245).

Lapisan analisis kedua adalah praktik kewacanaan atau fase interpretasi. Praktik kewacanaan menganalisis bagaimana dan dalam kondisi seperti apa suatu teks dan wacana diproduksi. Dalam tahap ini analisis difokuskan pada interpretasi teks, konteks situasional dan tipe diskursus, serta konteks intertekstualitas Aspek penting yang perlu diperhatikan adalah keberadaan intertekstualitas dan interdiskursivitas dalam teks (Kristeva, 1980).
Intertekstualitas merujuk pada bagaimana suatu teks dibangun dari teksteks yang lain. Sementara itu, interdiskursivitas merujuk pada keberadaan struktur wacana yang membentuk suatu teks. (Fairclough, 1989).

Lapisan analisis ketiga adalah analisis praktik sosial. Analisis praktik sosial merujuk pada bagaimana wacana dipraktikan dalam kehidupan seharihari. Dalam hal ini, aktivitas seseorang mereproduksi ataupun memproduksi suatu wacana menjadi fokus dalam analisis praktik sosial.

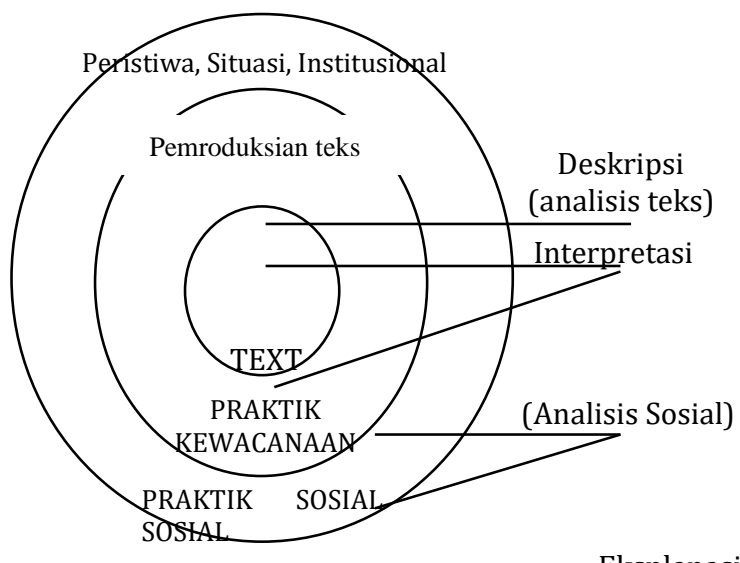

Eksplanasi

Gambar 1. Model Critical DiscoursesAnalysis

Sumber: Norman Fairclough, Discourse and Social Change (Cambridge: Polity Press, 1993), hlm. 226.

Ketiga lapisan analisis dalam CDA menyediakan seperangkat metode analisis yang mendalam yang mencakup ranah linguistik, sosial, dan kultural. Dalam konteks pembelajaran sejarah konstruktivistik, ketiga lapisan tersebut dapat digunakan untuk menilai 
perkembangan sistem dan struktur berpikir dari peserta didik. Oleh karena itu, metode CDA perlu dikembangkan dalam bentuk kajian konseptual penilaian pembelajaran konstruktivistik dengan pendekatan CDA.

\section{Penilaian Pembelajaran Sejarah Konstruktivistik melalui CDA}

Penilaian pembelajaran sejarah konstruktivistik dengan pendekatan Critical Discourse Analysis (CDA) dapat digunakan untuk menganalisis hasil kerja peserta didik. Hasil kerja peserta didik yang dapat dianalisis dengan pendekatan CDA berbentuk tes uraian seperti constructed response test atau tes membangun jawaban ataupun dengan tipe extended response serta tes uraian bebas dalam bentuk esai terstruktur. Constructed response text adalah tes subyektif, dimana peserta didik membangun jawaban secara mandiri (Budiyono, 2015). Sifat constructed mengekspresikan argumentasi dan gagasannya secara bebas, terbuka dan fleksibel (Widoyoko, 2014).

Bentuk tes tersebut mendorong peserta didik untuk menjawab pertanyaan sesuai dengan sistem dan struktur berpikir yang dimilikinya, sehingga memungkinkan pendidik dan peneliti untuk menganalisis jawaban peserta didik dan mengukur tingkat pencapaian kognitif dari peserta didik. Melalui keterbukaan tersebut peserta didik mendapatkan ruang untuk mencurahkan argumentasi dan wacana mereka dalam kertas kerja.

Hasil kerja peserta didik dianalisis dengan menggunakan pendekatan CDA untuk mengetahui tingkat perkembangan kognitif dan afektif. Dalam penilaian, pendidik menganalisis kata dan kalimat yang memiliki tendensi dan predisposisi yang menunjukkan tingkat pencapaian kognitif dan afektif peserta didik. Oleh karena itu, pendidik sebaiknya terlebih Tabel 1. Rubrik Ancangan CDA

\begin{tabular}{cl}
\hline $\begin{array}{c}\text { Tingkat Analisis Critical } \\
\text { Discourse Analysis }\end{array}$ & \multicolumn{1}{c}{ Indikator } \\
\hline Teks & $\begin{array}{l}\text { Kata, kalimat atau pernyataan yang mengarah pada tendensi dan sentimen- } \\
\text { sentimen yang lain } \\
\text { Kutipan-kutipan yang digunakan oleh peserta didik dalam kertas kerja } \\
\text { Praktik Wacana }\end{array}$ \\
yang menunjukan jaringan teks dan wacana \\
Praktik Sosial & sanggahan \\
\hline
\end{tabular}

tersebut diwujudkan dalam bentuk extended response test. Extended response test merupakan bentuk tes yang memungkinkan peserta didik untuk menjawab, mengorganisasikan dan dahulu membuat rubrik ancangan yang digunakan untuk menganalisis wacana peserta didik. Rubrik ancangan tersebut dirumuskan berdasarkan tiga lapisan 
analisis CDA sebagaimana dapat dilihat pada Tabel 1.

Rubrik ancangan CDA tersebut digunakan sebagai titik tumpu dalam menelaah hasil kerja peserta didik yang berbentuk tes uraian. Setelah dianalisis dengan menggunakan rubrik ancangan CDA, pendidik perlu mengkonversikan dan menyimpulkan hasil analisis tersebut dalam perkembangan sistem dan struktur berpikir peserta didik.

Sistem dan struktur berpikir dapat diamati dengan menggunakan taksonomi pembelajaran. Dalam hal ini, pendidik perlu merumuskan kata kunci yang merujuk pada taksonomi pembelajaran. Kata kunci tersebut ditempatkan dalam rubrik penilaian tingkat kognitif dan afektif. Selain kata kunci, pendidik juga merumuskan tingkat pencapaian berdasarkan taksonomi pembelajaran Bloom (1965) serta Anderson dan Krathwolh (2015). Kerangka rubrik penilaian perkembangan tingkat berpikir peserta didik di ranah kognitif dapat dilihat dalam tabel 2 .

Tabel 2. Rubrik Penilaian Tingkat Berpikir Siswa Ranah Kognitif

\begin{tabular}{|c|c|c|}
\hline Tingkatan Taksonomi & Kategori & Indikator \\
\hline Mengingat & Mengingat & Mampu mengingat tokoh dan peristiwa sejarah \\
\hline \multirow{3}{*}{ Memahami } & Mengklasifikasikan & $\begin{array}{l}\text { Mengkategorikan peristiwa sesuai dengan kronologi } \\
\text { waktu }\end{array}$ \\
\hline & Membandingkan & $\begin{array}{l}\text { Mampu membandingkan kondisi pada masa lalu } \\
\text { dengan kondisi masa sekarang }\end{array}$ \\
\hline & Menjelaskan & Menjelaskan sebab dan latar belakang suatu peristiwa \\
\hline Mengaplikasikan & Mengimplementasikan & $\begin{array}{l}\text { Menggunakan teori-teori dan } \\
\text { pendekatan untuk menjelaskan } \\
\text { peristiwa }\end{array}$ \\
\hline \multirow[t]{2}{*}{ Menganalisis } & Mengorganisasi & $\begin{array}{l}\text { Menyusun data sejarah menjadi bukti yang } \\
\text { mendukung penjelasan historis }\end{array}$ \\
\hline & Mengatribusi & Mengambil sudut pandang dalam penjelasan sejarah \\
\hline Mengevaluasi & Mengkritik & $\begin{array}{l}\text { Menentukan suatu metode atau solusi terbaik dari } \\
\text { delapan nilai-nilai asthabrata }\end{array}$ \\
\hline \multirow{2}{*}{ Mencipta } & Merencanakan & Merencanakan solusi masalah \\
\hline & Memproduksi & Menghasilkan argumentasi, fakta dan sanggahan \\
\hline
\end{tabular}


Berpijak pada tiga jenis rubrik tersebut, pendidik dapat menilai perkembangan sistem dan struktur berpikir peserta didik. Rubrik serupa juga dapat dikembangkan untuk menilai tingkat perkembangan afektif dan psikomotorik peserta didik. Setelah mengetahui posisi dari tingkat perkembangan sistem dan struktur berpikir peserta didik, maka pendidik dapat mengkonversikan tingkat capaian peseta didik.

Kajian awal mengenai konsep penilaian pembelajaran sejarah konstruktivistik dengan pendekatan CDA ini masih perlu dikembangkan. Jenis penilaian ini bersifat subyektif, sehingga sulit untuk mengukur validitas dan reliabilitas dari instrumen. Oleh karena itu, penguatan rubrik menjadi bagian penting dalam penilaian pembelajaran sejarah konstruktivistik. Dengan demikian, penilaian pembelajaran sejarah konstruktivistik ini diharapkan dapat menjadi alternatif penilaian pembelajaran yang tidak hanya menilai kuantitas pengetahuan siswa saja, tetapi juga mengukur perkembangan sistem dan struktur berpikir dari peserta didik.

\section{PENUTUP}

Konstruktivisme dalam ranah pendidikan memandang bahwa peserta didik secara otonom membangun atau mengkonstruksi pengetahuan dan kecerdasan melalui interaksi dengan dunia fisik dan sosial. Dua hal penting dalam pembelajaran sejarah kontruktivisme adalah perkembangan sistem dan struktur berpikir peserta didik serta, sifat multiple reality yang menghasilkan dilema dalam proses penilaian pembelajaran. Tulisan ini mendiskusikan mengenai penilaian dalam pembelajaran sejarah konstruktivistik dengan pendekatan Critical Discourse Analysis (CDA). Secara teoretik, CDA memuat seperangkat metode atau cara untuk mengetahui perkembangan sistem dan struktur kognitif, afektif dan psikomotorik peserta didik. CDA terdiri dari tiga lapisan analisis yang dinamis dan terkait satu sama lain yaitu: (1) analisis teks, (2) analisis praktik kewacanaan, dan (3) analisis praktik sosial.

Hasil kerja peserta didik yang dapat dianalisis dengan pendekatan CDA berbentuk tes uraian seperti constructed response test atau tes membangun jawaban ataupun dengan tipe extended response, serta tes uraian bebas dalam bentuk esai terstruktur. Constructed response text adalah tes subyektif, dimana peserta didik membangun jawaban secara mandiri. Jawaban peserta didik bersifat terbuka, sehingga memungkinkan dosen dan peneliti untuk menganalisis jawaban peserta didik dan mengukur tingkat pencapaian kognitif dan peserta didik. Jawaban peserta didik kemudian 
dianalisis dengan menggunakan pendekatan CDA untuk mengetahui tingkat perkembangan kognitif dan afektif. Pendidik perlu merumuskan rubrik ancangan CDA dan penilaian pembelajaran konstruktivistik. Menggunakan dua rubrik tersebut, pendidik dapat menilai pembelajaran sejarah konstruktivistik yang mencakup penilaian terhadap perkembangan sistem dan struktur berpikir peserta didik.

\section{REFERENSI}

Anderson, L.W. dan Krathwolh, D. 2015. Pembelajaran, Pengajaran dan Assesmen. Yogyakarta: Pustaka Pelajar

Bloom, B. 1965, Taxonomy of Educational Objectives: The Classification of Educational Goals, Handbook II: Affective Domain. New York: David McKay Company

Budiyono. 2015. Pengantar Penilaian Hasil Belajar. Surakarta: UNS Press

Carr, E.H. 2008. Apa itu Sejarah? Jakarta: Komunitas Bambu

Fairclough, N. 1989. Language and Power. Essex: Longman Group

Fairclough. 1993. Discourse and Social Change. Cambridge: Polity Press

Foucault, M. 1980. Power/Knowledge: Selected Interviews and Other Writings 1972-1977. New York: Pantheon Books

Gillis, J.R. 1996. Commemorations: The Politics of Nation Identity. New Jersey: Priceton University Press

Gottschalk, L. 2008. Mengerti Sejarah, Jakarta: UI Press
Ibrahim, A. S. 2009. Metode Analisis Teks \& Wacana. Yogyakarta: Pustaka Pelajar

Illeris, K. 2011. Contemporary Theories of Learning: Teori-teori Pembelajaran Kontemporer. Bandung: Nusa Media

Johnson, D.W. dan Johnson, R.T. 2002. Meaningful Assesment. Boston: Allyn and Bacon

Kuntowijoyo. 2013. Pengantar Ilmu Sejarah. Yogyakarta: Tiara Wacana

Kristeva, J. 1980. Desire in Language: A Semiotic Approach to Literature and Art. Columbia University Press

Muijs dan Reynold. 2008. Effective Teachng: Teori dan Aplikasi. Yogyakarta: Pustaka Pelajar

Popham, W. 1995. Classroom Assesment. Boston: Allyn and Bacon

Reynold, C.R., Livingstone, R. B., dan Wilson, V. 2010. Measurement and Assesment in Education: Second Edition. London: Pearson Education Rogers, R. 2004, An Introduction: Critical Discourse Analysis in Education. New Jersey: Lawrence Erlbaum Associates

Schunk, D. E. 2012. Learning Theories: An Educational Perspective. Yogyakarta: Pustaka Pelajar

Suharsimi, A. 2012. Dasar-dasar Evaluasi Pendidikan. Jakarta: Bumi Aksara

Suparman, A. 2012. Desain Instruksional Modern: Panduan Para Pengajar dan Inovator Pendidikan. Jakarta: Erlangga

Walshaw, M. 2007. Working with Foucault in Education. Rotterdam: Sense Publishers 
Widoyoko, E. P. 2014, Teknik Penyusunan Instrumen Penelitian. Yogyakarta: Pustaka Pelajar. 